\title{
Introduction
}

Open

\section{What Do We Know about the Patterns and Determinants of Female Entrepreneurship across Countries?}

\author{
Maria Minniti ${ }^{\mathrm{a}}$ and Wim Naudé ${ }^{\mathrm{b}, *}$

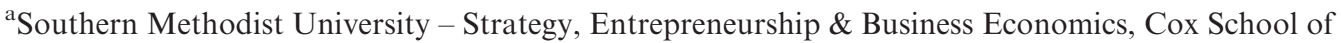 \\ Business, Dallas, TX 75275, USA. \\ ${ }^{\mathrm{b}}$ World Institute for Development Economics Research, United Nations University, \\ Katajanokanlaituri 6B, Helsinki 00160, Finland. \\ *E-mail:Wim@wider.unu.edu
}

\begin{abstract}
In this article we provide an introduction to the papers in the special section of this edition of the European Journal of Development Research. We start by framing the challenges posed by female entrepreneurship to the research community, note some of the findings in the literature pertaining to the cross-national understanding of female entrepreneurship, and review the existing literature on the role and experience of female entrepreneurs in developing countries. Despite progress in understanding the motivations, constraints and issues that confront female entrepreneurs, there is still substantial scope for further research. We then discuss four papers that advance this research agenda.
\end{abstract}

Dans ce papier nous introduisons les articles composant la rubrique de ce numéro du European Journal of Development Research. Cette rubrique est consacrée aux modèles et déterminants de l'entreprenariat féminin dans les différents pays, et se penche plus particulièrement sur le cas des pays en voie de développement. Dans un premier temps, nous présentons les défis que représente la question de l'entreprenariat féminin pour la communauté scientifique, nous décrivons quelques uns des résultats de la littérature concernant la conception trans-nationale de l'entreprenariat féminin, et passons en revue la littérature portant sur le rôle et les expériences des femmes entrepreneurs dans les pays en voie de développement. Bien que l'on comprenne de mieux en mieux les motivations des femmes entrepreneurs, ainsi que les contraintes et problèmes auxquels elles font face, ces questions méritent des recherches plus approfondies. Nous présentons ensuite quatre articles qui font progresser cet agenda de recherche.

European Journal of Development Research (2010) 22, 277-293. doi:10.1057/ejdr.2010.17 Published online 13 May 2010

Keywords: entrepreneurship; women; developing countries

The online version of this article is available Open Access

\section{Introduction}

Female entrepreneurship matters for individuals, for communities and for countries. Studying female entrepreneurship contributes to our understanding of entrepreneurship and human behaviour in general, and allows researchers to ask questions that shed light not only on why women behave the way they do but also on the linkages between entrepreneurship and wealth creation, employment, human capital accumulation, labour market dynamics and many others.

In recent years, the rate of new business formation by women has outpaced significantly the rate of new business formation by men across all ethnic groups in the United States (CWBR, 2004). Similar trends have been found across the developing world. However, females still own and manage significantly fewer businesses than men. The explanation for 
this as well as the behaviour of female entrepreneurs in terms of traits, motivations and success rates, and its gender-related distinctiveness is complex and multifaceted. Despite a growing literature, it remains the case, as Greene et al (2007) pointed out, that we need more research on female entrepreneurship, echoing De Bruin et al's (2006, p. 585) observation that female entrepreneurship is 'vastly understudied'.

Understanding the differences and commonalities across individuals and across countries is an important step in understanding female entrepreneurship, as well as its causes and effects, and its potential implications for policy. In the latter regard, the growing number of initiatives aimed at promoting entrepreneurship in developing countries, and particularly at empowering women in the process, should take such differences and commonalities into account.

This article provides an introduction and an overview to the papers contained in this special section of the journal. In the next section we profile female entrepreneurship across countries. In the subsequent section we discuss the role and experience of women entrepreneurs in developing countries, comparing it to that of women entrepreneurs elsewhere. In the penultimate section we provide a short overview of the papers contained in this special section. The last section concludes and provides suggestions for further research.

\section{Female Entrepreneurship Across Countries}

The past 30 years have seen significant changes in the status and political weight of women entrepreneurs, as well as a rapid increase of interest and research on the topic. In fact, starting with the first papers in the early 1970s, research on female entrepreneurship has expanded to a variety of disciplines, methods and countries.

Research in the 1970s and 1980s was rooted in early-trait psychology. Most of these studies did not test theory but, rather, considered gender as a variable (Greene et al, 2007). Thus, much research of the time focused on who the woman entrepreneur was (Birley et al, 1987; Holmquist and Sundin, 1988), or on how women entrepreneurs compared to men entrepreneurs (Sexton and Kent, 1981; Masters and Meier, 1988). This concern with individual characteristics emerged from the hope of developing an 'ideal profile' of the entrepreneur and aimed at identifying and recording those characteristics that separated entrepreneurs from other individuals.

The early 1990s, as women gained more prominent roles as both entrepreneurs and political actors, saw studies of female entrepreneurial behaviour being inspired by feminist theories (Hurley, 1999; Greer and Greene, 2003). Most feminism-inspired studies remained empirical, however, and did not address theoretical issues explicitly (Snyder, 1995). At about the same time, in an alternative to the feminist approach, a significant impact on the study of women's employment choices came from economics when, in 1990, Claudia Goldin published her book Understanding the Gender Gap. Although her book did not address self-employment or entrepreneurship explicitly, it legitimized the study of women's labour behaviour and, together with studies by Blau (Blau and Ferber, 1987; Blau, 1998; Blau and Kahn, 2007) and Nobel laureate Gary Becker (Becker, 1965), inspired a significant amount of research, both theoretical and empirical, on issues linking female entrepreneurship to the allocation of family resources, marriage and childbearing decisions, opportunity perceptions, self-confidence and poverty, among others.

By the end of the 1990s, the field of female entrepreneurship was established as a wellrespected and defined area of academic inquiry and female entrepreneurship had become a 
popular argument for the media and for political debates on employment and labour markets. In addition to women entrepreneurs' professional characteristics and achievements, research has been conducted on issues related to health, motherhood, family position and life style satisfaction (see Schindehutte et al, 2003; Williams, 2004, among others). Increased attention has also been paid to entrepreneurial teams and networks (see Aldrich et al, 2002; Greve and Salaff, 2003, among others), and to the study of femaleowned businesses, covering subjects such as growth and performance, management style, financing, human capital, labour markets and social entrepreneurship, among others (see Bird and Brush, 2002; Burke, 2002; Carter, 2003; Stewart et al, 2003).

What are the stylized facts we have learned from the past 30 years of research on women self-employment and new business creation? We now know that significantly fewer women than men own and manage businesses worldwide (Devine, 1994a, b; Georgellis and Wall, 2005; Kim, 2007). This could be because women fail more often than men or because fewer women than men start businesses to begin with, or both. Some evidence exists that, after correcting for factors such as size of the business and sectoral distribution, women's failure rates are not significantly different from those of men (Kalleberg and Leicht, 1991; Perry, 2002; Kepler and Shane, 2007). Thus, at least a portion of the difference between genders must be due to the fact that fewer women than men start businesses. Evidence to date suggests that a variety of reasons contribute to explaining observed differences in entrepreneurial behaviour across gender and that such differences have significant implications at the macroeconomic level (Minniti et al, 2006). Perhaps women and men have different socioeconomic characteristics and, if we were to correct for factors such as education, wealth, family and work status, those differences would disappear. Indeed, quite a bit of empirical evidence shows that such differences do exist (Cowling and Taylor, 2001; Blanchflower, 2004; Minniti et al, 2005). Also, women tend to possess fewer years of experience then men (Aronson, 1991; Lee and Rendall, 2001) and tend to concentrate in different sectors (Coleman, 2000; Orser et al, 2006; Allen et al, 2007). In addition, the propensity of women to start a business may differ from that of men for cultural reasons or because of discrimination (for example Neumark and McLennan, 1995). One could also argue that men and women have different preferences and that women like being self-employed less than men do (Kanazawa, 2005).

The businesses owned and managed by men and women are also different. We now know that women's businesses tend to be smaller and to grow less than those owned by men (DuReitz and Henrekson, 2000; Coleman, 2007). Also, women's businesses tend to be less profitable than those of men (Robb and Wolken, 2002) and to generate lower sales turnover than men, even in same-industry comparisons (Chaganti and Parasuraman, 1996). Minniti (2009) provides a comprehensive and up-to-date review of the literature on women entrepreneurs and their businesses.

For the purpose of this issue, the main question is whether the characteristics and role of female entrepreneurship vary across countries at different stages of development. Recent evidence shows that prevalence rates of female entrepreneurship tend to be relatively higher in developing than in developed countries (Minniti et al, 2006). This has traditionally been explained by the fact that in developing economies women face higher barriers to entry in the formal labour market and have to resort to entrepreneurship as a way out of unemployment and, often, out of poverty.

In general, interest in female entrepreneurship in developing countries has significantly increased. This is owing to at least two related reasons. First, it is due in part to the general increase in interest for the role of entrepreneurship in the economic development process 
(Gries and Naudé, 2010; Naudé, 2010). Following the end of the Cold War, the gradual but extensive market-strengthening reforms in China since the late 1970s, the failure of the state-led model of import substitution in Africa, the rapid growth of world trade, and the rising contribution of innovation to productivity, it is now generally recognized that entrepreneurship is important in economic growth (Audretsch et al, 2006; Minniti, 2008; Naudé, 2008, 2010; Naudé et al, 2008). In the process of entrepreneurship in developing countries, females have been assigned a special role because they stand to benefit from entrepreneurship as the poorer and discriminated against gender, but also because they are seen as a critical driver of entrepreneurship in light of their unique role in the household, and in light of the rise in female-headed households across the developing world (Horrell and Krishnan, 2007).

The second reason for the rise of interest in female entrepreneurship in developing countries is owing to the rapid increase in the number and proportion of female entrepreneurs in the developing world (Kevane and Wydick, 2001), and the insight that female-led micro- and small enterprises (MSEs) can have a more significant impact on overall household welfare and consumption than male-led MSEs. Women entrepreneurs and heads of household tend to spend more on household health, nutrition and education than men, and tend to employ proportionately more females than male-headed firms (Nichter and Goldmark, 2009).

In light of these reasons, supporting and expanding female entrepreneurship has become a worthwhile objective not only to empower women, ${ }^{1}$ but also to reduce poverty in developing countries. ${ }^{2}$ This is, among others, an important motivation behind the extensive and 'dramatic' increase in micro-credit directed at female entrepreneurs in developing countries in recent years (Kevane and Wydick, 2001). ${ }^{3}$

\section{Female Entrepreneurship in Developing Countries}

The entrepreneurial process is characterized by at least four phases, ${ }^{4}$ the conception phase, when the would-be entrepreneur perceives an opportunity, the gestation phase when the opportunity is evaluated, the infancy phase when the firm is created and the adolescence phase (Reynolds, 1993, p. 14). In addition, the phase of firm closure (exit) has also been the subject of scrutiny, given the high rates of observed firm closures and inter-generational (family) firm changes. Also, many entrepreneurs, after having gone through these phases, are habitual entrepreneurs and will start over again.

\section{The Conception and Gestation Phases}

During the conception phase latent entrepreneurs are considering seeking or are actively seeking entrepreneurial opportunities. In the OECD, about 25 per cent of the labour force has been found to be latent entrepreneurs (Blanchflower et al, 2001, p. 680).

During this phase entrepreneurs need the alertness to perceive and act on opportunities (Gaglio and Katz, 2001; Licht, 2007) and the ability to function under uncertainty and risk (Kihlstrom and Laffont, 1979). The psychological (individual-level) aspect that influences these abilities has not been adequately researched in the context of developing countries. However, three issues in particular have been noted.

The first is the apparent lack of interest by many poor people to seek opportunities. In a recent review of the behaviour of the extremely poor (those living on less than US\$1 per day), 
Banerjee and Duflo (2007, p. 165) were perplexed by the apparent lack of opportunity perception of the poor, and wrote 'one senses a reluctance of poor people to commit themselves psychologically to a project of making more money'. This may, however, not only reflect a lack of psychological commitment, but also that entrepreneurs have limited attention, and that the environment in poor countries is such that women, in particular, face a very high opportunity cost for turning attention away from pressing matters to seek or perceive new opportunities - which may be scarce (Gifford, 1998, p. 17).

The second is that for households at subsistence level, assuming the high risk of exploiting opportunities subject to uncertainty may be unacceptable - the potential losses may outweigh the potential gains.

Third, as Luke and Munshi (2010) discuss, women are often less able to respond to opportunities owing to cultural or business environment restrictions. Gender beliefs are often restrictive, so that women do not identify with entrepreneurship and do not search for opportunities. Garcia-Cabrera and Garcia-Soto (2008) find evidence for this from Cape Verde. However, to the extent that traditional cultures have isolated women from many economic activities, Luke and Munshi (2010) argue that they may be more responsive to new opportunities because they 'have fewer ties to the traditional economy to hold them back' (ibid, p. 16).

\section{The Infancy (Start-up) Phase}

Economic theory has approached the decision of an individual to start a firm as an occupational choice between self-employment and wage employment (Evans and Jovanovic, 1989). Ceteris paribus, a person will become an entrepreneur if profits from self-employment exceed wage income plus additional benefits from being in wage employment. The factors that affect this occupational choice have also been found to be fairly similar in developing and developed country settings (Maloney, 2004). They include an individual's entrepreneurial ability (Åstebro and Bernhardt, 2005), relative returns to entrepreneurship (Murphy et al, 1991), capital constraints (Banerjee and Newman, 1993), entry costs (Djankov et al, 2002) and factors that influence the opportunity costs of becoming self-employed such as social security (Fonseca et al, 2007).

In developing countries the role of entrepreneurial ability has also been found to be among the most important determinants of the decision of an individual to become an entrepreneur, and of the subsequent success of the firm. Entrepreneurial ability is most often measured by educational status and experience. Formal education is important for forming entrepreneurial ability, and, particularly in developing countries, so is vocational training (Goedhuys and Sleuwaegen, 2000). Experience is also important and, in developing countries, it can compensate for education. Nafziger and Terrell (1996), for example, found from a study of Indian entrepreneurs that age, experience and background can compensate for lack of education in start-up rates and the success of the firm, and Naudé and Rossouw (2010) found that experience is an important determinant of the speed and extent to which Chinese entrepreneurs internationalize their firms.

These considerations are particularly important for women. In developing countries, because of disadvantages and discrimination in education and the labour market, women most often do not have the same entrepreneurial experience as men. Moreover, with perceived underinvestment in their human capital, many women may not have sufficient confidence in their ability to start a firm (Langowitz and Minniti, 2007). Yueh (2009) discusses 
the case of women entrepreneurs in China and supports the idea that lack of self-confidence is a significant constraint hindering women entrepreneurial entry in developing countries.

As in developed countries, credit and start-up costs have been identified as significant constraints to firm start-ups in developing countries, possibly affecting women more than men. Horrell and Krishnan (2007), for example, report that female-headed households often lack either assets or incomes, or both, and that this constrains their ability to diversify their economic activities. In this regard a large number of studies have found that access to micro-credit has improved women's decision-making autonomy (Amin et al, 1998), and general household welfare and consumption (Kevane and Wydick, 2001). Barriers to entry in the form of start-up costs often reflect the regulatory environment of a country, and the 'ease of doing business' (see Naudé et al, 2008; Gries and Naudé, 2009 and also the paper by Hampel-Milagrosa in this special section). They may reduce new firm creation, the formalization of firms and firm growth (for example Beck et al, 2003).

Whereas entrepreneurial ability and relative rates of return affect individuals' decisions to become entrepreneurs similarly in developing and developed countries, and whereas prospective entrepreneurs often face broadly similar constraints in the form of access to finance and start-up costs, what may be different in developing countries is the extent to which entrepreneurs rely on social networks. Social networks can be both supportive and inhibiting of entrepreneurial activities. Yueh (2009) discusses the case of social networks in China, noting that the country's institutional environment is characterized by 'an incomplete legal system affording limited protection to private assets, credit constraints for private enterprises, and regulatory opacity' (ibid, p. 778). In such weak institutional environments, social networks can play an important role in overcoming obstacles to starting a firm.

Women in developing countries, like their counterparts in more developed ones, rely more than men on extended families (Brush, 1992; Greve and Salaff, 2003; Justo and DeTienne, 2008), which, in many rural settings are often their only or major social network. This is often constraining since women's marriage status, and the assets and incomes brought to their marriages, emerge as important determinants of their entrepreneurial decisions (Nichter and Goldmark, 2009). Maloney (2004) reports that in Argentina, Brazil, Costa Rica and Mexico, married women with young children are more likely to enter entrepreneurship than wage labour. Married women are more likely to be entrepreneurs than non-married women, but they are also more likely to quit a business voluntarily (Justo and DeTienne, 2008). ${ }^{5}$ Entrepreneurship is a career choice that does not pay on average. Hamilton (2000) has shown that, except for the highest 25 per cent of entrepreneurial incomes, staying in a wage job or moving back to it makes more economic sense than starting a new business. Women in particular have been found to earn less as entrepreneurs, and this has given rise to a substantial literature exploring women's motivations and aspirations as entrepreneurs (more in the next section). Generally, it is agreed that women often (but not always) have different aspirations than men, and may start firms with non-pecuniary motives in mind. As summarized by Justo and DeTienne (2008) more women than men are likely to start a new firm owing to the greater flexibility this provides for balancing work and family responsibilities. This, of course, explains at least in part why women entrepreneurs earn less than their male counterparts. ${ }^{6}$

\section{The Mature (Growth) Phase}

If a new venture survives the dangerous infancy stage and becomes an established firm, it may or may not achieve growth in sales, or in the number of workers employed, or both. 
Most start-ups in developing countries are MSEs employing less than five workers. On average 61 per cent of all MSEs in Africa and Latin America are female-owned (Nichter and Goldmark, 2009). In these countries, the evaluation of how women's firms grow relative to those of men is complicated by the fact that we know very little about MSE growth (Nichter and Goldmark, 2009). Existing literature has established that (i) most firms do not grow at all and that average growth in employment in firms is driven by a few firms growing very rapidly - called 'gazelles' - and (ii) that smaller (and younger) firms tend to grow faster and have higher and more variable growth rates (Jovanovic, 1982; Cabral and Mata, 2003; Desai et al, 2003). This is the case also in developing countries. Nichter and Goldmark (2009), for example, report that surveys of firms in Africa and Latin America have found that less than 3 per cent of MSEs expand by four or more employees. Informal firms tend to grow even more slowly, presumably reflecting their more restricted credit market access (Nichter and Goldmark, 2009).

When considering gender differences, evidence on whether women's firms grow more slowly than men's in developed countries is mixed. Storey (1994) finds no statistically significant differences between male- and female-owned firms' growth, but Carter and Allen (1997) find that female firm growth in the United States was slower than that of male firms, and their firms were consequently smaller, among others, owing to a lack of access to finance. Somewhat in contrast, evidence for developing countries suggests that women's firms tend to grow slower in both sales and employment (Amine and Straub, 2009; Nichter and Goldmark, 2009) even if one controls for sectors. Women are also found to have lower growth expectations (Justo and DeTienne, 2008). But the literature also notes exceptions. For instance, Kevane and Wydick (2001), studying a sample of Guatemalan entrepreneurs, could not find any significant difference in sales growth between male- and female-owned firms and no difference in employment growth between male-owned and firms owned by females over 30 years of age. ${ }^{7}$ Robson and Obeng (2008), using a sample of 500 Ghanaian entrepreneurs, found that female-owned firms experienced the same obstacles faced by male-owned firms. And Storey (2004) found no evidence from a sample of entrepreneurs from Trinidad and Tobago that female-owned firms are discriminated against in credit markets.

Overall, women's lower average entrepreneurial ability, propensity to enter informal sector firms, family networks and inhibiting cultural institutions, non-growth aspirations and a business environment that often discriminates against them, are all factors that can explain the slower growth of female-headed firms in developing countries.

\section{Firm Exit}

The exit rate of new firms (or rate of firm turnover) is high in all countries. Hopenhayn (1992, p. 1127) notes that in the United States about 40 per cent of manufacturing firms exit within 5 years. Cressy (2006) cites the finding that 50 per cent of firms exit the market after only 18-24 months. Female-owned firm exit rates tend to be higher than those of males across countries (Rosti and Chelli, 2005; Fairlie and Robb, 2009) and their survival rates lower than those of male-owned firms (see for example Mead and Liedholm, 1998). Moreover, in developing countries, firms in rural areas are more likely to fail than firms in urban areas (Liedholh, 2002).

Entrepreneurial exit does not necessarily imply firm failure ${ }^{8}$ (Andersson, 2006). Most firm exits have been found to be voluntary (up to 80 per cent) (Taylor, 1999). Justo and deTienne (2008) note that firm exit is more likely to be voluntary in the case of women 
than in the case of men. Reasons for women to voluntarily exit a firm include increases in the opportunity costs of being self-employed owing to, for example, improvements in macroeconomic conditions (Andersson, 2006) or an increase in the time required for dealing with family matters. ${ }^{9}$ Women also retire and pass their firms on to a new generation an event more likely in the case of women-owned firms (Kanniainen and Poutvaara, 2007).

Improvements in macroeconomic conditions may have both positive and negative effects on the rate of self-employment. On the one hand, it may send a signal of potentially good returns to innovation for high-ability entrepreneurs, leading them to enter and remain in the market. On the other hand, higher wages imply increased opportunity costs of entrepreneurship for entrepreneurs with relatively better ability as workers. In the presence of labour market rigidities, this may lead to a self-selection of the most highly talented women into the labour markets. As a result, less talented women will opt for selfemployment, a characteristic reflected in their lower survival rates (see for example Rosti and Chelli, 2005).

Improving women's educational status may thus have mixed impacts on firm survival. Although it may prolong survival for the reasons noted, it may also be the case that better educated female entrepreneurs can earn higher wages so that they will be among the first to exit. Nafziger and Terrell (1996, p. 695) point out that formal education often does not contribute to entrepreneurial ability, as they found in a sample from India that new firms established by formally well-educated entrepreneurs are less likely to survive because their founders face better opportunities in wage-employment and rent-seeking.

A third category of motivations for entrepreneurial exit concerns the retirement of the entrepreneur. In this case, a successful firm will either be discontinued, sold on the market to another entrepreneur or passed on to a new generation within the family. ${ }^{10}$ Kanniainen and Poutvaara (2007) show that informational failures exist in the market for firms, and that this will result in a tendency for high-quality firms to be more often transferred within a family than sold to external entrepreneurs. Given that these informational failures tend to be more prevalent in poor and developing countries, one could expect a predominance of (less efficient) family-owned firms in these countries. Parker (2007) also suggests a predominance of family firms in countries in which property rights and legal protection for investors are weak, since keeping the firm within the family may reduce 'costly monitoring' of outside entrepreneurs. Because many women entrepreneurs in developing countries are predominantly in family firms, this would suggest that female ownership of firms be more associated with firms being passed on to a new generation than being sold on the market.

\section{Habitual Entrepreneurship}

Entrepreneurs who discontinue a firm and exit the market often start a new firm. This has been termed 'renascent' entrepreneurship (Stam et al, 2007) or 'habitual' entrepreneurship, which includes 'serial' entrepreneurs, and 'portfolio' entrepreneurs (Ucbasaran et al, 2006, pp. $4-5){ }^{11}$

Stam et al (2007) investigated the extent and determinants of renascent entrepreneurs, and found that whether a person starts a new firm after having failed the first time depends on his or her capacity to learn from experience. According to Ucbasaran et al (2006, p. 25) women are less likely than men to become habitual entrepreneurs, and if they do, are more likely to become serial rather than portfolio entrepreneurs. In addition, habitual entrepreneurs have been found to be significantly motivated by non-pecuniary benefits, such as a desire for independence (Ucbasaran et al, 2006). Holmes and Schmitz (1990) 
model habitual entrepreneurs as resulting from the 'occupational' decision of individuals wishing to specialize in entrepreneurship and whose investments in new firms are essentially investments in their own entrepreneurial ability. Giannetti and Simonov (2004) emphasized the importance of social norms in an entrepreneur's decision to start (and re-start) a firm, as these will determine whether or not there is a stigma attached to failure.

Habitual entrepreneurs seem to make up a significant proportion of the self-employed in developed countries, and one may expect the same to be the case in developing countries. There is, however, a gap in the literature on the extent and motivations of serial entrepreneurship in developing countries. A noteworthy recent contribution is Li et al (2009) who discuss serial entrepreneurship in China, and find that serial entrepreneurs do learn from experience but that this does not necessarily lead to better firm performance. The evidence on habitual women entrepreneurs in developing countries is particularly scanty. Nichter and Goldmark (2009) and Downing and Daniels (1992) have found that women's primary concern in these countries is survival rather than growth. Thus, it is possible that women wishing to diversify income sources may opt for portfolio entrepreneurship by creating additional firms rather than becoming serial entrepreneurs.

To sum up, the role played by female entrepreneurship on aggregate economic activity, as well as the role played, in turn, by alternative degrees of economic development on female participation in self-employment, remain (despite our growing knowledge) among the least studied and potentially most important areas in the entrepreneurship and development literatures. The purpose of this special issue is to stimulate further debate on these important topics.

\section{Overview of the Papers in This Special Section}

The four papers contained in this special section of the journal attempt to further the debate on female entrepreneurship across countries and in developing countries. They are grounded in a variety of disciplines and take different, albeit complementary, approaches. This highlights the cross-disciplinary nature of entrepreneurship studies, as well as the complexity and breadth of the issues under study.

In the first paper, Female Entrepreneurship and Economic Activity, Minniti provides an exploratory investigation of the variables associated with the entrepreneurial gender gap. This entails asking what variables are systematically associated with female entrepreneurship, and whether they vary when countries at various levels of economic development are considered. Making use of equalized bootstrapping, a non-parametric technique, Minniti shows that the variables associated to entrepreneurial decisions tend to be the same for men and women and across countries, regardless of the level of development. However, she also shows that the intensity with which each of these variables influences individuals does vary significantly across gender and across countries depending on their level of development.

Interestingly, the macroeconomic environment has a greater impact on the entrepreneurial decisions of women than on those of men, whereas several objective individuallevel characteristics such as incomes, wealth, age and work status appear to have limited explanatory power. Instead, subjective and possibly biased perceptions about selfconfidence, fear of failure and existence of opportunities emerge as significantly and systematically associated with gender differences in entrepreneurial behaviour across all countries in her sample. 
Consistent with existing literature, Minniti finds that differences in entrepreneurial behaviour between men and women are remarkably stable across countries and participation rates for men tend to be 50 per cent higher than those of women. Her findings also suggests that larger gender gaps in start-up activity are found in middle-income countries, whereas they tend to be narrower in lower-income countries, probably because many women start businesses out of necessity. Surprisingly, women in poorer countries tend to be more self-confident about their abilities (skills and knowledge) to become entrepreneurs and less afraid of failure compared to women in middle-and high-income countries.

The second paper, by Terjesen and Amorós is entitled Female Entrepreneurship in Latin America and the Caribbean: Characteristics, Drivers and Relationship to Economic Development. It addresses three questions: what proportion of women in Latin America is involved in entrepreneurial activities? What institutions facilitate or hinder their decisions to enter into entrepreneurship? And what is the impact of these women, if any, on the economic development of their countries?

The authors show that average rates of women entrepreneurship are relatively high in Latin America and the Caribbean but that significant heterogeneity exists across countries, with about only 3 per cent of the female adult population of Puerto Rico involved in start-up activity as opposed to about 35 per cent in Peru. Furthermore, they show that institutions matter for the rate of opportunity-driven female entrepreneurship. However, they also find the dummy variable for Latin America to be positive and significant. This suggests that Latin America's relatively high rate of female entrepreneurship may be the result of the proxy variables chose as large proportions of women entrepreneurs in the region are found to be necessity-motivated entrepreneurs. Only 13 per cent of women entrepreneurs in the region indicated that they expected their firm to grow over the following 5 years. The authors document 'opportunities and incentives are unfavorable for women to begin businesses', even when they have the abilities and knowledge.

The third paper is entitled Gendered Institutions and Cross-National Patterns of Business Creation for Men and Women. In this paper, Elam and Terjesen expand further the study of heterogeneity in female start-up rates across countries introduced by Terjesen and Amorós. They begin by noting that while a growing body of research has focused on the differences in start-up rates between countries at various levels of development and with different structural features (as in the paper by Minniti), it is also the case that considerable variation in the gender gap remains among countries with similar levels of national wealth, and that economic factors do not fully explain observed gender patterns of start-up activity.

The main purpose of their paper is therefore to explain the gender gap in start-up activity in countries with similar economic levels of development, taking into consideration non-economic factors such as culture and institutions. In particular, the authors are concerned with isolating the impact of what they term 'gendered institutions' or 'gender culture' on the decision of a person, whether male or female, to start a new firm.

Using measures of sectoral employment, the gender wage gap, female business leadership and public expenditures on childcare, the authors use a two-level randomcoefficient logistic regression model to identify whether these factors influence the decision of women with respect to entrepreneurship. Interestingly, their results show no direct effects for any of these variables, but do show important and significant interaction effects. This suggests that these variables may not influence start-up rates directly but, rather, influence individual perceptions. The authors conclude by noting that there is much scope 
for further research, particularly with respect to obtaining better cross-national data, and data on the impact of formal institutions on gender.

The final paper in the special section dealing with female entrepreneurship across countries and in development is entitled Raising the Benchmark: Identifying and Addressing Gender Issues in Doing Business. In this paper, Hampel-Milagrosa asks whether business regulations have a discriminatory impact on women, and, if so, how should business regulations be reformed to promote female entrepreneurship. Within this context, Hampel-Milagrosa's paper focuses on the World Bank's Doing Business Indicators (DBIs), which provide annual information on the extent of business regulations across 181 countries. While the previous papers addressed the gender gap in entrepreneurship across countries, and the reasons for such a gap within countries, Hampel-Milagrosa is concerned about changes and reforms in business regulations and how the latter may contribute to lowering the potential barriers faced by women.

The paper shows that, contrary to common wisdom, the reforms that the World Bank can inspire based on the DBIs may not be sufficient to overcome barriers to women's entry into entrepreneurship and could conceivably even have a negative effect. As a way forward, she suggests that the DBI's approach needs to be complemented by a mix of qualitative and quantitative research on the level of traditions, norms and beliefs towards women. Specifically, she recommends the inclusion of qualitative measures of gender discrimination at the level of regulations, as well as a possible 'Gender Index' reflecting the degree of discrimination faced by women when starting and doing business.

\section{Concluding Remarks}

Although much has been accomplished in the field of female entrepreneurship, it is clear that, far from being exhausted, the field lends itself to a variety of extensions and further investigations (Minniti, 2009).

First, theoretical developments have not kept pace with the large amount of empirical studies. Theorists interested in developing model of female entrepreneurial behaviour will have their work read with great interest.

Second, a significant and yet unresolved issue concerns what variables should enter the utility function of individuals when studying their allocation of time between household production, wage labour and self-employment - particularly in developing economies and when alternative views of the familial unit are considered. And when applied to serial entrepreneurship, the theoretical and empirical literature has very little to say on females in developing countries.

Third, questions related to cultural factors and migrations among the self-employed provide another very fertile area of inquiry for both theory and empirical work, with the possibility of making not only a significant contribution to science, but also to policy and management practices. As migration remains an important coping mechanism in the face of development shocks, further research would be very desirable, especially at the underresearched intersection between gender, ethnicity and migrant status.

Fourth, discrimination has been suggested as a possible explanation for the gender gap in entrepreneurship and this is likely to be more significant in poorer countries although the evidence is mixed. As we noted, discrimination against women is often the result of gender beliefs inherent in a culture or society. This may have the effect of not only reducing women's 
likelihood of becoming entrepreneurs and their earnings as entrepreneurs, but may also reduce the non-pecuniary benefits women receive from entrepreneurship.

Fifth, very little is known about how the level of aggregate activity influences women's decisions about entrepreneurship and even less is known about how the latter contribute to growth. Although a significant amount of anecdotal evidence and some very good case studies exist on this topic, the lack of a systematic approach and data have prevented, so far, the formulation of a comprehensive and robust theory of female entrepreneurship and growth. Of course, no 'women only' theory is necessary. However, a solid understanding of how the distinctive characteristics of female entrepreneurship are accounted by the existing models of growth would be very desirable for both science and policy.

Finally, the study of institutions and how they promote or discourage female entrepreneurship is particularly needed for its policy implications, especially in developing countries where issues of institutional development have been emphasized in recent years (Naudé, 2010). Within this context, a post-institutional approach based on insights from economics and organization theory seems promising (Reskin and Bielby, 2005), as well as economic approaches that integrate tools and methods from anthropology and ethnography (Chamlee-Wright, 1997; Minniti, 2010).

In conclusion, we trust that our introduction has conveyed a sense of the complexity of the issues involved in female entrepreneurship, and we hope to have brought across a better appreciation of the multi-varied and dynamic role played by female entrepreneurs across countries and in developing countries in particular.

\section{Acknowledgement}

The papers contained in this special section of the European Journal for Development Research have been prepared for the UNU-WIDER project on Promoting Entrepreneurial Capacity, directed by Wim Naudé. The papers were first presented at the Project Meeting 'Entrepreneurship and Economic Development' held in Helsinki, Finland on 21-23 August 2008. Papers were subsequently revised, and submitted to a double-blind refereeing process. We are grateful to the journal's Editorial Team, in particular Rajneesh Narula (Chief Editor) and Barbara Coghlan for facilitating the publication of this issue. We also thank the many referees for their role in the evaluation and selection of the papers, and Barbara Fagerman, Neha Mehrotra, Liisa Roponen and Lisa Winkler for their valuable administrative assistance to the project. UNU-WIDER gratefully acknowledges the financial contribution to the project by the Finnish Ministry for Foreign Affairs, and the financial contributions to the research programme by the governments of Denmark (Royal Ministry of Foreign Affairs), Finland (Ministry for Foreign Affairs), Norway (Royal Ministry of Foreign Affairs), Sweden (Swedish International Development Cooperation Agency - Sida) and the United Kingdom (Department for International Development).

\section{Notes}

1. By opening up entrepreneurial opportunities to women, entrepreneurship may in itself contribute towards women's empowerment and welfare, because it will raise the returns from investing in women's education (Fafchamps and Quisumbing, 2005).

2. As Anderson and Eswaran (2009) note, by empowering women (that is improving their autonomy) entrepreneurship can contribute towards lower child and infant mortality and better health and educational outcomes in developing countries.

3. As Kevane and Wydick (2001) pointed out, already by 2001 around 93 per cent of the Grameen Bank's 1.2 million borrowers were female entrepreneurs. 
4. These phases correspond approximately to Shane and Venkataraman's (2000) description of entrepreneurship as consisting of the identification, evaluation and exploitation of opportunities.

5. As Fafchamps and Quisumbing (2005, p. 2) pointed out, 'In agrarian societies marriage is an event of deep economic importance. First, it typically marks the onset not only of a new household but also of a new production unit, for example, a family farm. Assets brought to marriage determine the start-up capital of this new enterprise'. From a data set covering rural Ethiopia, Fafchamps and Quisumbing show that the family network of a women and her marriage partner has a large impact on the start-up capital the new household/family firm receives. In their sample they also find that grooms contribute on average 10 times more assets at marriage than brides - suggesting that the disproportionate bargaining power of males in the household may constrain the woman's future options. Fafchamps and Quisumbing therefore conclude that women's prospects in rural settings in developing countries will be improved if there were to be more off-farm income-earning opportunities, including the option of opportunities through self-employment.

6. Part of the differential of course, may be due to discrimination. For instance, Glick and Sahn (1997), using data from Guinea, found that 45 per cent of the earnings differential between males and females in self-employment was owing to discrimination against women.

7. Only for firms headed by females younger than 30 years did they find reduced employment growth, ascribing this to the impact of women's childbearing years.

8. It is often desirable that unproductive and inefficient firms fail, as this allows resources to be allocated to more efficient uses. Alvarez and Vergara (2010) argue that in developing countries firm exit may result from government interventions and market failures.

9. While women may exit because of differences in aspirations and family obligations, the latter can also contribute to women continuing in entrepreneurship even if their firms are not performing well (Gimeno et al, 1997; Justo and deTienne, 2008).

10. Bertrand and Schoar (2006) provide a survey of the recent research into family entrepreneurship, in particularly discussing efficiency-based and cultural theories of family businesses.

11. Serial entrepreneurs are defined as 'individuals who have sold or closed at least one business ... and currently have a minority or majority ownership stake in a single independent business', whereas portfolio entrepreneurs are defined as 'individuals who currently have minority or majority ownership stakes in two or more independent businesses' (Ucbasaran et al, 2006, p. 5).

\section{References}

Aldrich, H.E., Carter, N. and Ruef, M. (2002) With very little help from their friends: Gender and relational composition of nascent entrepreneurs' startup teams. Frontiers of Entrepreneurship Research 2002. Babson Park, MA: Babson College.

Allen, E., Langowitz, N. and Minniti, M. (2007) The 2006 Global Entrepreneurship Monitor Special Topic Report: Women in Entrepreneurship. Center for Women Leadership, Babson College. Babson Park, MA.

Alvarez, R. and Vergara, S. (2010) Exit in developing countries: Economic reforms and plant heterogeneity. Economic Development and Cultural Change 58: 537-556.

Amin, R., Becker, S. and Bayes, A. (1998) NGO-promoted micro-credit programs and women's empowerment in rural Bangladesh: Quantitative and qualitative evidence. Journal of Developing Areas 32(2): 221-236.

Amine, L.S. and Straub, K.M. (2009) Women entrepreneurs in Sub-Saharan Africa: An institutional theory analysis from a social marketing point of view. Entrepreneurship and Regional Development 21(2): 183-211.

Anderson, S. and Eswaran, M. (2009) What determines female autonomy? Evidence from Bangladesh. Journal of Development Economics 90: 179-191.

Andersson, P. (2006) Determinants of exits from self-employment. Essay IV in a $\mathrm{PhD}$ Thesis in Economics, Swedish Institute for Social Research, Stockholm University.

Aronson, R.L. (1991) Self-Employment: A Labor Market Perspective. Ithaca, NY: ILR Press.

Åstebro, T. and Bernhardt, I. (2005) The winner's curse of human capital. Small Business Economics 24: $63-78$. 
Audretsch, D.B., Keilbach, M.C. and Lehmann, E.E. (2006) Entrepreneurship and Economic Growth. Oxford: Oxford University Press.

Banerjee, A. and Newman, A. (1993) Occupational choice and the process of development. Journal of Political Economy 101(2): 274-298.

Banerjee, A.V. and Duflo, E. (2007) The economic lives of the poor. Journal of Economic Perspectives 21(1): 141-167.

Beck, T., Demirguc-Kunt, A. and Levine, R. (2003) Small and Medium Enterprises, Growth, and Poverty: Cross-Country Evidence. World Bank Policy Research Working Paper 3178. December.

Becker, G. 1965 A theory of the allocation of time. Economic Journal 75: 493-517.

Bertrand, M. and Schoar, A. (2006) The Role of Family in Family Firms. The Journal of Economic Perspectives 20(2): 1-17.

Bird, B.J. and Brush, C.G. (2002) A gendered perspective on organizational creation. Entrepreneurship Theory and Practice 26(3): 41-65.

Birley, S., Moss, C. and Saunders, P. (1987) Do women entrepreneurs require different training? American Journal of Small Business 12(1): 27-35.

Blanchflower, D.G. (2004) Self-employment: More may not be better. Swedish Economic Policy Review 11: 15-73.

Blanchflower, D.G., Oswald, A.J. and Stutzer, A. (2001) Latent entrepreneurship across nations. European Economic Review 45: 680-691.

Blau, F.D. (1998) Trends in the well-being of American women, 1970-1995. Journal of Economic Literature 36(1): 112-165.

Blau, F.D. and Ferber, M.A. (1987) Discrimination: Empirical evidence from the United States. The American Economic Review 77(2): 316-321.

Blau, F.D. and Kahn, L.M. (2007) Changes in the labor supply behavior of married women: 1980-2000. Journal of Labor Economics 25(3): 393.

Brush, C.G. (1992) Research on women business owners: Past trends, a new perspective and future directions. Entrepreneurship Theory and Practice 16(4): 5-31.

Burke, A.E. (2002) Self-employment wealth and job creation: The roles of gender, non-pecuniary motivation and entrepreneurial ability. Small Business Economics 19(3): 255-270.

Cabral, L. and Mata, J. (2003) On the evolution of the firm size distribution: Facts and theory. American Economic Review 93(4): 1075-1090.

Carter, N.M. (2003) The career reasons of nascent entrepreneurs. Journal of Business Venturing 18(1): 13-39.

Carter, N.M. and Allen, K.R. (1997) Size determinants of women-owned businesses: Choice or barriers to resources? Entrepreneurship and Regional Development 9(3): 211-220.

Chaganti, R. and Parasuraman, S. (1996) A study of the impact of gender on business performance and management patters in small businesses. Entrepreneurship Theory and Practice 21(2): 73-85.

Chamlee-Wright, E. (1997) The Cultural Foundations of Economic Development. London and New York: Routledge.

Coleman, S. (2000) Access to capital and terms of credit: A comparison of men- and women-owned small businesses. Journal of Small Business Management 38(3): 37-52.

Coleman, S. (2007) The role of human and financial capital in the profitability and growth of women-owned small firms. Journal of Small Business Management 45(3): 303-319.

Cowling, M. and Taylor, M. (2001) Entrepreneurial women and men: Two different species? Small Business Economics 16(3): 167-176.

Cressy, R. (2006) Why do most firms die young? Small Business Economics 26: 103-116.

CWBR - Center for Women's Business Research. (2004) Women Owned Businesses in 2004: Trends in the U.S. and 50 States. Washington D.C: Center for Women's Business Research.

De Bruin, A., Brush, C.G. and Welter, F. (2006) Introduction to the special Issue: Towards building cumulative knowledge on women's entrepreneurship. Entrepreneurship Theory and Practice 30(5): 585-593.

Desai, M., Gompers, P. and Lerner, J. (2003) Institutions, Capital Constraints, and Entrepreneurial Firm Dynamics: Evidence from Europe. Cambridge, MA: National Bureau for Economic Research. NBER Working Paper 10165.

Devine, T.J. (1994a) Changes in wage-and-salary returns to skill and the recent rise in female self-employment. The American Economic Review 84(2): 108-112. 
Devine, T.J. (1994b) Characteristics of self-employed women in the United States. Monthly Labor Review 117(3): 20-34.

Djankov, S., La Porta, R., Lopez-de-Silanes, F. and Schleifer, A. (2002) The regulation of entry. Quarterly Journal of Economics 118: 1-37.

Downing, J. and Daniels, L. (1992) The Growth and Dynamics of Women Entrepreneurs in Southern Africa. Washington DC: USAID. GEMINI Technical Report no. 47.

DuReitz, A. and Henrekson, M. (2000) Testing the female underperformance hypothesis. Small Business Economics 14: 1-10.

Evans, D.S. and Jovanovic, B. (1989) An estimated model of entrepreneurial choice under liquidity constraints. Journal of Political Economy 97(4): 808-827.

Fafchamps, M. and Quisumbing, A. (2005) Assets at marriage in rural Ethiopia. Journal of Development Economics 66: 225-269.

Fairlie, R.W. and Robb, A.M. (2009) Gender differences in business performance: Evidence from the characteristics of business owners survey. Small Business Economics 33(4): 375.

Fonseca, R., Michaud, P.-C. and Sopraseuth, T. (2007) Entrepreneurship, wealth, liquidity constraints, and start-up costs. Comparative Labor Law and Policy Journal 28: 637-674.

Gaglio, C.M. and Katz, J.A. (2001) The psychological basis of opportunity identification: Entrepreneurial alertness. Small Business Economics 16: 95-111.

Garcia-Cabrera, A.M. and Garcia-Soto, M. (2008) Cultural differences and entrepreneurial behaviour: An intra-country cross-cultural analysis in Cape Verde. Entrepreneurship and Regional Development 20(5): 451-483.

Georgellis, Y. and Wall, H. (2005) Gender differences in self-employment. International Review of Applied Economics 19: 321-337.

Giannetti, M. and Simonov, A. (2004) On the determinants of entrepreneurial activity: Social norms, economic environment and individual characteristics. Swedish Economic Policy Review 11: 269-313.

Gifford, S. (1998) Limited entrepreneurial attention and economic development. Small Business Economics 10: 17-30.

Gimeno, J., Folta, T.B., Cooper, A.C. and Woo, C.Y. (1997) Survival of the fittest? Entrepreneurial human capital and the persistence of underperforming firms. Administrative Science Quarterly 42: $750-783$.

Glick, P. and Sahn, D. (1997) Gender and education impacts on employment and earnings from Conakry, Guinea. Economic Development and Cultural Change 45: 793-824.

Goedhuys, M. and Sleuwaegen, L. (2000) Entrepreneurship and growth of entrepreneurial firms in Côte D'Ivoire. Journal of Development Studies 36(3): 122-145.

Goldin, C. (1990) Understanding the Gender Gap: An Economic History of American Women. New York: Oxford University Press.

Greene, P.G., Brush, C.G. and Gatewood, E. (2007) Perspectives on women entrepreneurs: Past findings and new directions. In: M. Minniti (ed.) Entrepreneurship: The Engine of Growth, Vol. 1. - Perspective Series. Westport, CT, USA and London, UK: Praeger Publisher - Greenwood Publishing Group.

Greer, M.J. and Greene, P.G. (2003) Feminist theory and the study of entrepreneurship. In: J.E. Butler (ed.) New Perspectives on Women Entrepreneurs. Greenwich, CT: Information Age Publishing, pp. 1-24.

Greve, A. and Salaff, J.W. (2003) Social networks and entrepreneurship. Entrepreneurship Theory and Practice 28(1): 1-22.

Gries, T. and Naudé, W.A. (2009) Entrepreneurship and regional economic growth: Towards a general theory of start-ups. Innovation: The European Journal of Social Science Research 22(3): 309-328.

Gries, T. and Naudé, W.A. (2010) Entrepreneurship and structural economic transformation. Small Business Economics Journal 34(1): 13-29.

Hamilton, B.A. (2000) Does entrepreneurship pay? An empirical analysis of the returns to selfemployment. Journal of Political Economy 108(3): 604-631.

Holmes, T.J. and Schmitz, J.A. (1990) A theory of entrepreneurship and its application to the study of business transfers. Journal of Political Economy 98(2): 265-294.

Holmquist, C. and Sundin, E. (1988) Women as entrepreneurs in Sweden: Conclusions from a survey. Frontiers of Entrepreneurship Research 1988: 626-642. 
Hopenhayn, H.A. (1992) Exit, entry and firm dynamics in long-run equilibrium. Econometrica 60(5): $1127-1150$.

Horrell, S. and Krishnan, P. (2007) Poverty and productivity in female-headed households in Zimbabwe. Journal of Development Studies 43(8): 1351-1380.

Hurley, A. (1999) Incorporating feminist theories into sociological theories of entrepreneurship. Women in Management Review 14: 54-62.

Jovanovic, B. (1982) Selection and evolution of industry. Econometrica 50(3): 649-670.

Justo, R. and DeTienne, D.R. (2008) Gender, Family Situation and the Exit Event: Reassessing the Opportunity-Cost of Business Ownership. Madrid. IE Business School Working Paper WP08-26.

Kalleberg, A.L. and Leicht, K.T. (1991) Gender and organizational performance: Determinants of small business survival and success. Academy of Management Journal 34(1): 136-161.

Kanazawa, S. (2005) Is 'discrimination' necessary to explain the sex gap in earnings? Journal of Economic Psychology 26(2): 269-287.

Kanniainen, V. and Poutvaara, P. (2007) Imperfect transmission of tacit knowledge and other barriers to entrepreneurship. Comparative Labor Law and Policy Journal 28: 675-693.

Kepler, E. and Shane, S. (2007) Are male and female entrepreneurs really that different? The Office of Advocacy Small Business Working Papers, http://www.sba.gov/.

Kevane, M. and Wydick, B. (2001) Microenterprise lending to female entrepreneurs: Sacrificing economic growth for poverty alleviation? World Development 29(7): 1225-1236.

Kihlstrom, R.E. and Laffont, J.-J. (1979) A general equilibrium entrepreneurial theory of firm formation based on risk aversion. Journal of Political Economy 87(4): 719-748.

Kim, G. (2007) The analysis of self-employment levels over the life-cycle. Quarterly Review of Economics and Finance 47(3): 397.

Langowitz, N. and Minniti, M. (2007) The entrepreneurial propensity of women. Entrepreneurship Theory and Practice 31(3): 341-365.

Lee, M.A. and Rendall, M.S. (2001) Self-employment disadvantage in the working lives of blacks and females. Population Research and Policy Review 20: 291-320.

Li, S., Schulze, W. and Li, Z. (2009) Plunging into the sea again? a study of serial entrepreneurship in China. Asia Pacific Journal of Management 26: 667-680.

Licht, A.N. (2007) The entrepreneurial spirit and what the law can do about it. Comparative Labor Law and Policy Journal 28: 817-862.

Liedholh, C. (2002) Small firm dynamics: Evidence from Africa and Latin America. Small Business Economics 18(1): 227.

Luke, N. and Munshi, K. (2010) Women as agents of change: Female income and mobility in India. Journal of Development Economics, doi: 10.1016/j.jdeveco2010.10.002.

Maloney, W.F. (2004) Informality revisited. World Development 32(7): 1159-1178.

Masters, R. and Meier, R. (1988) Sex differences and risk-taking propensity of entrepreneurs. Journal of Small Business Management 26(1): 31-35.

Mead, C.D. and Liedholm, C. (1998) The dynamics of micro and small enterprises in developing countries. World Development 26(1): 61-74.

Minniti, M. (2008) The role of government policy on entrepreneurial activity: Productive, unproductive, or destructive? Entrepreneurship Theory and Practice 32(5): 779-790.

Minniti, M. (2009) Gender issues in entrepreneurship. Foundations and Trends in Entrepreneurship 5(7-8): 497-621.

Minniti, M. (2010) Entrepreneurship, poverty and institutions. Manuscript.

Minniti, M., Allen, E. and Langowitz, N. (2006) The 2005 Global Entrepreneurship Monitor Special Topic Report: Women in Entrepreneurship. Center for Women Leadership, Babson College. Babson Park, MA.

Minniti, M., Arenius, P. and Langowitz, N. (2005) The 2004 Global Entrepreneurship Monitor Special Topic Report: Women in Entrepreneurship. Center for Women Leadership, Babson College. Babson Park, MA.

Murphy, K., Schleifer, A. and Vishny, R. (1991) The allocation of talent: Implications for growth. Quarterly Journal of Economics 106(2): 503-530.

Nafziger, E.W. and Terrell, D. (1996) Entrepreneurial human capital and the long-run survival of firms in India. World Development 24(4): 689-696.

Naudé, W.A. (2008) Entrepreneurship in Economic Development. United Nations University, Helsinki, Finland. WIDER Research Paper RP 2008/20. 
Naudé, W.A. (2010) Entrepreneurship, developing countries and development economics: New approaches and insights. Small Business Economics Journal 34(1): 1-12.

Naudé, W.A., Gries, T., Wood, E. and Meintjes, A. (2008) Regional determinants of entrepreneurial start-ups in a developing country. Entrepreneurship and Regional Development 20(2): 111-124.

Naudé, W.A. and Rossouw, S. (2010) Early international entrepreneurship in China: Extent and determinants. Journal of International Entrepreneurship 8(1): 87-111.

Neumark, D. and McLennan, M. (1995) Sex discrimination and women's labor market outcomes. The Journal of Human Resources 30: 713-740.

Nichter, S. and Goldmark, L. (2009) Small firm growth in developing countries. World Development 37(9): 1453-1464.

Orser, B.J., Riding, A.L. and Manley, K. (2006) Women entrepreneurs and financial capital. Entrepreneurship Theory and Practice 30(5): 643-665.

Parker, S.C. (2007) Law and the economics of entrepreneurship. Comparative Labor Law and Policy Journal 28: 695-716.

Perry, S. (2002) A comparison of failed and non-failed small businesses in the United States. Journal of Developmental Entrepreneurship 7: 415-428.

Reskin, B.F. and Bielby, D.D. (2005) A sociological perspective on gender and career outcomes. The Journal of Economic Perspectives 19(1): 71-86.

Reynolds, P.D. (1993) The role of entrepreneurship in economic systems: Developed market and post-socialist economies. Paper presented at the Second Freiberg Symposium on Economics; 9-11 September, Freiberg.

Robb, A. and Wolken, J. (2002) Firm, Owner, and Financing Characteristics: Differences between Female- and Male-owned Small Businesses. FRBG Working paper.

Robson, P.J.A. and Obeng, B.A. (2008) The barriers to growth in Ghana. Small Business Economics 30: $385-403$.

Rosti, L. and Chelli, F. (2005) Gender discrimination, entrepreneurial talent and self-employment. Small Business Economics 24: 131-142.

Schindehutte, M., Morris, M. and Brennan, C. (2003) Entrepreneurs and motherhood: Impacts on their children in South Africa and the United States. Journal of Small Business Management 41(1): 94-107.

Sexton, D.L. and Kent, C.A. (1981) Female executives and entrepreneurs: A preliminary comparison. In: K.H. Vesper (ed.) Frontiers of Entrepreneurship Research. Boston, MA: Babson College, pp. $40-55$.

Shane, S. and Venkataraman, S. (2000) The promise of entrepreneurship as a field of research. Academy of Management Review 25(1): 217-226.

Snyder, M.G. (1995) Feminist theory and planning theory: Lessons from feminist epistemologies. Berkley Planning Journal 10: 91-106.

Stam, E., Audretsch, D. and Meijaard, J. (2007) Renascent entrepreneurship: Entrepreneurial preferences subsequent to firm exit. Paper presented at the Babson College Entrepreneurship Conference in 2006.

Stewart Jr, W.H., Carland, J.C., Carland, J.W., Watson, W. and Sweo, R. (2003) Entrepreneurial dispositions and goal orientations: A comparative exploration of United States and Russian entrepreneurs. Journal of Small Business Management 41(1): 27-46.

Storey, D. (1994) Understanding the Small Business Sector. London: Routledge.

Storey, D. (2004) Racial and gender discrimination in the micro firms credit market? Evidence from Trinidad and Tobago. Small Business Economics 23(5): 401.

Taylor, M.P. (1999) Survival of the fittest? An analysis of self-employment duration in Britain. The Economic Journal 109: C140-C155.

Ucbasaran, D., Westhead, P. and Wright, M. (2006) Habitual Entrepreneurs. Cheltenham, UK: Edward Elgar.

Williams, D.R. (2004) Effects of childcare activities on the duration of self-employment in Europe. Entrepreneurship Theory and Practice 28(5): 467-485.

Yueh, L. (2009) China's entrepreneurs. World Development 37(4): 778-786.

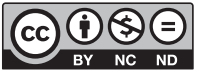

This work is licensed under a Creative Commons Attribution-NonCommercial-NoDerivative Works 3.0 Unported License. To view a copy of this license, visit http://creativecommons.org/licenses/by-nc-nd/3.0/ 